\title{
Pengaruh Penerapan Model Argument Driven Inquiryterhadap Keterampilan Berpikir Kritis Siswa SMP Berdasarkan Perbedaan Gaya Belajar
}

\author{
I Kadek Irfando Dwikki Sadewa*, Undang Rosidin, dan I Wayan Distrik \\ Fakultas Keguruan dan IImu Pendidikan, Universitas Lampung \\ *E-mail: kadekirfando@gmail.com
}

\begin{abstract}
Abstrak
Penelitian ini bertujuan untuk mengetahui pengaruh penerapan model Argument Driven Inquiry (ADI) terhadap keterampilan berpikir kritis siswa SMP berdasarkan perbedaan gaya belajar. Sampel penelitiannya, yaitu siswa kelas VIIIA dan VIIIC SMP Negeri 1 Seputih Banyak. Penelitian menggunakan metode quasi eksperiment dengan desain faktorial 2x3. Data dianalisis dengan uji Two Way Anova. Berdasarkan hasil penelitian diperoleh rerata pretest kelas eksperimen dan kontrol yaitu 25,38 dan 17,31. Setelah penerapan model ADI pada kelas eksperimen dan kontrol diperoleh rerata postest 60,86 dan 42,26. Berdasarkan hasil uji Two Way Anova model pembelajaran diperoleh nilai Sig. yaitu 0,000, maka terdapat pengaruh signifikan model ADI terhadap berpikir kritis siswa. Selanjutnya, nilai Sig. gaya belajar yaitu 0,011 berarti terdapat perbedaan keterampilan berpikir kritis ketiga tipe gaya belajar menggunakan model ADI. Hasil interaksi model pembelajaran dengan gaya belajar diperoleh nilai Sig. yaitu 0,017, sehingga terdapat interaksi antara model ADI dengan gaya belajar dalam peningkatan keterampilan berpikir kritis siswa.
\end{abstract}

Kata kunci: Argument Driven Inquiry, Keterampilan Berpikir Kritis, Gaya Belajar

\section{PENDAHULUAN}

Pendidikan adalah usaha sadar dan terencana untuk mewujudkan suasana belajar dan proses pembelajaran agar peserta didik secara aktif mengembangkan potensi dirinya untuk memiliki kekuatan spiritual keagamaan, pengendalian diri, kepribadian, kecerdasan, akhlak mulia, serta keterampilan yang diperlukan untuk kehidupan bermasyarakat, berbangsa dan bernegara (Permendikbud, 2016). Ada beberapa standar yang harus dipenuhi dalam pelaksanaan sistem pendidikan, salah satunya adalah Standar Proses.

Standar Proses adalah kriteria mengenai pelaksanaan pembelajaran pada satuan pendidikan untuk mencapai Standar Kompetensi Lulusan. Proses Pembelajaran pada satuan pendidikan diselenggarakan secara interaktif, inspiratif, menyenangkan, menantang, memotivasi pesertadidik untuk berpartisipasi aktif, serta memberikan ruang yang cukup bagi prakarsa, kreativitas, dan kemandirian sesuai dengan bakat, minat, dan perkembangan fisik serta psikologis peserta didik. Setiap satuan pendidikan melakukan perencanaan pembelajaran, pelaksanaan proses pembelajaran serta penilaian proses pembelajaran untuk meningkatkan efisiensi dan efektivitas ketercapaian kompetensi lulusan. Kompetensi lulusan ini merupakan kriteria mengenai kualifikasi kemampuan lulusan, salah satunya aspek keterampilan peserta didik (Permendikbud, 2016). Keterampilan peserta didik khususnya keterampilan berpikir yang didapatkan pada proses pendidikan adalah keterampilan berpikir kritis dimana keterampilan ini melatih kemampuan penalaran yang digunakan untuk memecahkan permasalahan.

Pembelajaran IPA Fisika yang ada di tingkat SMP merupakan salah satu proses yang dapat mengembangkan keterampilan berpikir kritis dengan mempelajari fenomena yang berlangsung di kehidupan sehari-hari yang memiliki nilai kongkret dan dapat dibuktikan dengan metode eksperimen dan menggunakan rumus-rumus atau persamaan secara matematis, hal tersebut dapat membantu siswa dalam pemahaman konsep sebagai syarat bahwa keberhasilan proses pembelajaran tercapai. Guru harus jeli dalam membuat strategi pembelajaran yang akan diterapkan dengan pemilihan 
penggunaan model pembelajaran yang tepat untuk tercapainya tujuan pembelajaran IPA yaitu peserta didik memiliki kompetensi dalam mengembangkan kemampuan berpikir dan menganalisis suatu masalah dengan menggunakan konsep dan prinsip IPA.

Berdasarkan hasil studi pendahuluan berupa wawancara dengn guru mata pelajaran IPA yang dilakukan pada 25 SMP di Bandar Lampung terhadap pengetahuan guru tentang keterampilan berpikir kritis dan sejauh mana kemampuan berpikir kritis yang dimiliki siswa. Data yang diperoleh yaitu $73 \%$ guru mengetahui apa itu keterampilan berpikir kritis dan telah mengupayakan munculnya keterampilan berpikir kritis pada pembelajaran IPA Fisika, namun dalam proses pembelajaran baru $19 \%$ siswa yang mampu memberikan penjelasan sederhana , $7 \%$ siswa mampu membangun keterampilan dasar, 20\% siswa mampu menyimpulkan, dan $8 \%$ siswa mampu memberikan penjelasan lanjut, serta $8 \%$ siswa mampu mengatur strategi dan taktik. Observasi ini juga menggali informasi siswa terhadap pengetahuan mereka mengenai kemampuan berpikir kritis yang dimana hasilnya $54 \%$ siswa menjawab belum mengetahui tentang keterampilan berpikir kritis. Hal ini disebabkan karena masih terdapat penggunaan model pembelajaran yang kurang tepat oleh banyak guru. Penggunaan model pembelajaran yang kurang tepat ini belum banyak disadari oleh guru bahwa hal tersebut akan berpengaruh dalam mengembangkan keterampilan berpikir kritis siswa.

Pemilihan model pembelajaran yang kurang tepat oleh guru dalam proses pembelajaran akan menimbulkan beragam masalah seperti rendahnya kemampuan siswa dalam menyelesaikan masalah yang mana dampak dari keterampilan berpikir kritis siswa yang relatif kurang. Pada prosesnya tujuan pembelajaran yang telah dirancang di awal tidak dapat tercapai dengan maksimal sebab siswa hanya mampu memperoleh hasil belajar dengan batas standar pencapaian atau KKM yang ditentukan tanpa membangun motivasi mereka untuk menyelesaikan permasalahan dengan baik.

Inilah yang menjadi suatu penelitian dalam pembelajaran yang akan dilakukan. Model pembelajaran yang diterapkan harus benar-benar bisa mengubah pola pembelajaran agar dapat meningkatkan suatu kemampuan berpikir kritis (Harie, 2015). Salah satu model yang dapat digunakan yaitu model pembelajaran Argument Driven Inquiry (ADI). Model pembelajaran ADI merupakan model pembelajaran yang dirancang untuk memberi pengalaman belajar yang efektif didalam kelas dan pengalaman yang lebih autentik pada pembelajaran laboratorium sains. Diharapkan dengan model ADI ini siswa tidak hanya menerima konsep dan pengetahuan secara pasif melainkan siswa dapat melakukan penyelidikan atau penemuan pengetahuan secara aktif dengan cara menyelesaikan permasalahan-permasalahan yang muncul. Pembelajaran berbasis laboratorium ini memunculkan kerjasama antar siswa tidak hanya dengan anggota kelompoknya bahkan dengan anggota dari kelompok lain, hal ini dapat dilihat pada saat hasil kerja kelompok dibagikan untuk dilakukan evaluasi oleh teman kelompok sendiri dan kelompok lain. Kemudian hasil yang diperoleh akan divalidasi dengan cara membandingkan hasil dari kelompok satu dengan kelompok lain. Pembelajaran berbasis laboratorium inilah yang diterapkan dalam model pembelajaran ADI (Phelps, 2012).

Proses pembelajaran materi di dalam kelas, setiap siswa pastinya memiliki karakteristik yang berbeda antara siswa satu dengan yang lainnya. Salah satu karakteristik tersebut yang perlu adanya perhatian pada proses pembelajaran adalah gaya belajar. Siswa akan mampu belajar secara maksimal apabila dapat belajar sesuai dengan gaya belajar yang ia miliki. Gaya belajar yang dimiliki oleh siswa juga akan berpengaruh terhadap pencapaiannya dalam proses pembelajaran dan pengembangan kompetensi yang dimiliki serta kemampuan berpikir kritisnya (Sularso, 2015). Perbedaan gaya belajar tersebut diantaranya belajar dengan cara melihat atau visual, belajar dengan cara mendengarkan atau auditorial, dan belajar dengan cara bergerak atau kinestetik. Perbedaan gaya belajar ini juga berdampak pada berbedanya tingkat keterampilan berpikir kritis antara gaya belajar visual, audiotorial, dan kinestetik. Berdasarkan uraian di atas maka penulis melakukan penelitian dengan judul "Pengaruh Penerapan Model Argument Driven Inquiry terhadap Keterampilan Berpikir Kritis Siswa SMP berdasarkan Perbedaan Gaya Belajar". 


\section{Desain Penelitian}

\section{METODE}

Penelitian ini menggunakan metode quasi experiment dengan desain faktorial $2 \times 3$. Desain faktorial digunakan untuk menyelidiki ada tidaknya pengaruh model pembelajaran ADI terhadap keterampilan berpikir kritis siswa dapat digeneralisasikan melalui ketiga tipe gaya belajar. Penelitian yang dilakukan menggunakan dua kelas yaitu kelas eksperimen dan kelas kontrol yang menjadi sampel. Tabel 1 berikut merupakan desain faktorial $2 \times 3$.

Tabel 1. Desain faktorial $2 \times 3$

\begin{tabular}{lccc}
\hline $\begin{array}{l}\text { Model Gaya Belajar } \\
\text { Pembelajaran }\end{array}$ & $\begin{array}{c}\text { Visual } \\
\left(\mathrm{B}_{1}\right)\end{array}$ & $\begin{array}{c}\text { Auditorial } \\
\left(\mathrm{B}_{2}\right)\end{array}$ & $\begin{array}{c}\text { Kinestetik } \\
\left(\mathrm{B}_{3}\right)\end{array}$ \\
\hline Argument Driven Inquiry $\left(\mathrm{A}_{1}\right)$ & $\left(\mathrm{A}_{1} \mathrm{~B}_{1}\right)$ & $\left(\mathrm{A}_{1} \mathrm{~B}_{2}\right)$ & $\left(\mathrm{A}_{1} \mathrm{~B}_{3}\right)$ \\
\hline Konvensional $\left(\mathrm{A}_{2}\right)$ & $\left(\mathrm{A}_{2} \mathrm{~B}_{1}\right)$ & $\left(\mathrm{A}_{2} \mathrm{~B}_{2}\right)$ & $\left(\mathrm{A}_{2} \mathrm{~B}_{3}\right)$ \\
\hline & & & \\
\hline
\end{tabular}

Materi pada penerapan model pembelajaran ini adalah pesawat sederhana. Jumlah pertemuan pada kelas eksperimen maupun kontrol sebanyak 4 kali pertemuan. Sebelum kegiatan pembelajaran dimulai, siswa diberikan angket gaya belajar untuk mengelompokkan tipe gaya belajar siswa dan diberikan soal pretest untuk mengukur kemampuan awal siswa.

Kegiatan tatap muka siswa melakukan penyelidikan sesuai LKPD yang telah diberikan, menganalisis data yang diperoleh untuk menghasilkan skema argumentasi berupa pertanyaan penelitian, klaim, bukti (data), dan pembenaran (warrant/backing) yang ditulis pada LKPD. Skema argumentasi tersebut digunakan untuk sesi diskusi interaktif, mengumpulkan argumentasi kelompok lain yang dikunjungi untuk menambah informasi dalam penyusunan laporan hasil diskusi kelompok. Kegiatan selanjutnya review laporan antar teman dan ditutup dengan kegiatan diskusi refleksi tentang penyelidikan yang telah dilakukan.

\section{Populasi dan Sampel Penelitian}

Populasi dalam penelitian ini adalah seluruh siswa kelas VIII semester genap SMP Negeri 1 Seputih Banyak tahun pelajaran 2018-2019. Sampel yang digunakan pada penelitian ini yaitu kelas VIII A sebagai kelas eksperimen yang diberikan penerapan model ADI dan kelas VIII C sebagai kelas kontrol yang menggunakan model konvensional (direct instruction).

\section{Variabel Penelitian dan Instrumen Pengumpulan Data}

Penelitian ini terdiri atas tiga variabel penelitian yaitu variabel bebas, variabel terikat, dan variabel moderat. Variabel bebas dalam penelitian ini adalah penerapan model pembelajaran Argument Driven Inquiry. Variabel terikatnya adalah keterampilan berpikir kritis siswa dan variabel moderatnya adalah perbedaan tipe gaya belajar siswa, yaitu visual, auditorial, dan kinestetik. Instrumen penelitian yang digunakan dalam penelitian ini adalah lembar tes untuk mengetahui keterampilan berpikir kritis siswa berupa soal uraian yang berjumlah 10 soal yang mengandung 5 indikator keterampilan berpikir kritis, yaitu: 1) memberikan penjelasan sederhana; 2) membangun keterampilan dasar; 3) menyimpulkan; 4) memberikan penjelasan lanjut; 5) strategi dan taktik (Ennis, 2011: 2-4). 10 soal tersebut terdiri dari 4 soal dengan kriteria memberikan penjelasan sederhana, 2 soal dengan kriteria membangun keterampilan dasar, 2 soal dengan kriteria memberikan penjelasan lanjut, 1 soal dengan kriteria strategi dan taktik, dan 3 soal lagi dengan kriteria menyimpulkan. Pengelompokkan tipe gaya belajar menggunakan angket dengan jumlah 30 butir pernyataan yang mengandung kriteria ketiga tipe gaya belajar yaitu visual, auditorial, dan kinestetik. Pemberian skor angket menggunakan skala likert yang memiliki kategori skor 1-4 yaitu tidak pernah, jarang, sering, selalu. Angket dan skala likert ini dirujuk dari sumber (Sugiyono, 2012). Sebelum digunakannya instrumen dalam sampel, instrumen diuji terlebih dahulu menggunakann uji validitas dengan dan uji reliabilitasnya dengan bantuan program SPSS. 


\section{Teknik Pengumpulan Data dan Analisis Data}

Pengumpulan data dilakukan dengan memberikan angket gaya belajar dan pretest sebelum pembelajaran serta postest setelah pembelajaran selesai dilaksanakan. Data yang telah diperoleh selanjutnya dianalisis dengan menggunakan (1) uji $N$-gain, (2) uji normalitas, (3) uji homogenitas, (4) uji Two Way Anova, (5) uji Post Hoc.

\section{HASIL DAN PEMBAHASAN}

Hasil

Hasil penelitian yang diperoleh berupa data kuantitatif (keterampilan berpikir kritis) yang terdiri dari nilai pretest dan postest, kemudian nilai pretest dan postest dihitung dengan uji $N$-gain untuk memperoleh nilai peningkatan keterampilan berpikir kritis siswa. Data nilai pretest, postest, dan $\mathrm{N}$ gain yang diperoleh diuji normalitas, uji homogenitas, dan uji Two Way Anova serta uji lanjut Post Hoc. Sebelum pembelajaran dilaksanakan, siswa diberikan angket pilihan pernyataan untuk mengelompokkan tipe gaya belajar siswa.

Data tipe gaya belajar siswa kelas eksperimen dan kelas kontrol yang diperoleh dapat dilihat pada Tabel 2.

Tabel 2. Data Tipe Gaya Belajar Siswa

\begin{tabular}{clcc}
\hline No & Tipe Gaya Belajar Siswa & Kelas Eksperimen (\%) & Kelas Kontrol (\%) \\
\hline $\mathbf{1}$ & Visual & 32,26 & 45,16 \\
$\mathbf{2}$ & Auditorial & 35,48 & 25,81 \\
$\mathbf{3}$ & Kinestetik & 32,26 & 29,03 \\
& Jumlah & 100 & 100 \\
\hline
\end{tabular}

Tabel 2 menunjukkan bahwa kelas eksperimen memiliki tipe gaya belajar visual sebanyak 10 siswa $(32,26 \%)$, auditorial sebanyak 11 siswa $(35,48 \%)$, dan kinestetik sebanyak 10 siswa $(32,26 \%)$. Sementara itu, kelas kontrol memiliki tipe gaya belajar visual sebanyak 14 siswa (45,16\%), auditorial sebanyak 8 siswa $(25,81 \%)$, dan kinestetik sebanyak 9 siswa $(29,03 \%)$.

Data rata-rata nilai siswa dan data rata-rata nilai siswa kelas eksperimen serta kelas kontrol berdasarkan tipe gaya belajar ditampilkan pada Tabel 3, Tabel 4, Tabel 5.

Tabel 3. Data Rata-rata Nilai Siswa

\begin{tabular}{cccccc}
\hline No & Parameter & \multicolumn{2}{c}{ Kelas Eksperimen } & \multicolumn{2}{c}{ Kelas Kontrol } \\
& & Pretest & Postest & Pretest & Postest \\
\hline 1 & Jumlah siswa & 31 & 31 & 31 & 31 \\
2 & Nilai teredah & 16,67 & 43,33 & 10,00 & 26,67 \\
3 & Nilai tertinggi & 53,33 & 80,00 & 30,00 & 56,67 \\
4 & Nilai maksimal & 100 & 100 & 100 & 100 \\
5 & Rata-rata nilai & 25,38 & 60,86 & 17,31 & 42,26 \\
\hline
\end{tabular}

Tabel 4. Data Rata-rata Nilai Siswa Kelas Eksperimen Tipe Gaya Belajar

\begin{tabular}{cccccccc}
\hline No & Parameter & \multicolumn{2}{c}{ Visual } & \multicolumn{2}{c}{ Auditorial } & \multicolumn{2}{c}{ Kinestetik } \\
& Pretest & Postest & Pretest & Postest & Pretest & Postest \\
\hline 1 & $\begin{array}{c}\text { Jumlah } \\
\text { siswa }\end{array}$ & 10 & 10 & 11 & 11 & 10 & 10 \\
2 & $\begin{array}{c}\text { Nilai } \\
\text { terendah } \\
\text { Nilai }\end{array}$ & 16,67 & 46,67 & 16,67 & 56,67 & 16,67 & 43,33 \\
3 & 46,67 & 76,67 & 53,33 & 80,00 & 50,00 & 80,00 \\
4 & $\begin{array}{c}\text { tertinggi } \\
\text { Nilai } \\
\text { maksimal } \\
5\end{array}$ & 100 & 100 & 100 & 100 & 100 & 100 \\
\hline $\begin{array}{c}\text { Rata-rata } \\
\text { nilai }\end{array}$ & 23,67 & 55,00 & 26,06 & 67,88 & 26,33 & 59,00 \\
\hline
\end{tabular}


Tabel 5. Data Rata-rata Nilai Siswa Kelas Kontrol Tipe Gaya Belajar

\begin{tabular}{cccccccc}
\hline No & Parameter & \multicolumn{2}{c}{ Visual } & \multicolumn{2}{c}{ Auditorial } & \multicolumn{2}{c}{ Kinestetik } \\
& & Pretest & Postest & Pretest & Postest & Pretest & Postest \\
\hline 1 & $\begin{array}{c}\text { Jumlah } \\
\text { siswa }\end{array}$ & 14 & 14 & 8 & 8 & 9 & 9 \\
2 & $\begin{array}{c}\text { Nilai } \\
\text { terendah }\end{array}$ & 10,00 & 30,00 & 10 & 56,67 & 10,00 & 26,67 \\
3 & $\begin{array}{c}\text { Nilai } \\
\text { tertinggi } \\
\text { Nilai }\end{array}$ & 30,00 & 56,67 & 26,67 & 80,00 & 26,67 & 53,33 \\
4 & 100 & 100 & 100 & 100 & 100 & 100 \\
5 & $\begin{array}{c}\text { maksimal } \\
\text { Rata-rata } \\
\text { nilai }\end{array}$ & 17,62 & 41,91 & 16,25 & 41,67 & 17,78 & 43,33 \\
\hline
\end{tabular}

Rata-rata nilai pretest dan postest kelas eksperimen lebih besar dibandingkan dengan rata-rata nilai pretest dan postest kelas kontrol. Tabel 4 menunjukkan tidak ada perbedaan yang jauh atau cenderung sama nilai rata-rata pretest kelas eksperimen pada gaya belajar visual, auditorial, kinestetik dan nilai rata-rata postest auditorial lebih besar dari kinestetik dan visual lebih kecil dari kinestetik. Tabel 5 nilai rata-rata pretest gaya belajar visual, auditorial, kinestetik pada kelas kontrol juga memiliki nilai yang cenderung sama, sedangkan nilai rata-rata postest tiga tipe gaya belajar juga memiliki nilai cenderung sama.

Data rata-rata $\mathrm{N}$-gain keterampilan berpikir kritis siswa dan $\mathrm{N}$-gain keterampilan berpikir kritis siswa berdasarkan tipe gaya belajar pada kelas eksperimen dan kelas kontrol dapat dilihat pada Tabel 6 dan Tabel 7.

Tabel 6. Data Rata-rata $N$-gain Keterampilan Berpikir Kritis Siswa

\begin{tabular}{ccc}
\hline Perolehan N-gain & Kelas Eksperimen & Kelas Kontrol \\
\hline N-gain tertinggi & 0,65 & 0,44 \\
N-gain terendah & 0,32 & 0,16 \\
Rata-rata N-gain & 0,48 & 0,30 \\
Kategori & Sedang & Sedang \\
\hline
\end{tabular}

Tabel 7. Data Rerata N-gain Berpikir Kritis Siswa Gaya Belajar Kelas Eksperimen dan kelas kontrol

\begin{tabular}{ccccccc}
\hline $\begin{array}{c}\text { Perolehan } \\
\text { N-gain }\end{array}$ & Visual & Kelas Eksperimen & \multicolumn{3}{c}{ Kelas Kontrol } \\
Auditorial & Kinestetik & Visual & Auditorial & Kinestetik \\
\hline $\begin{array}{c}\text { N-gain } \\
\text { tertinggi }\end{array}$ & 0,56 & 0,65 & 0,65 & 0,44 & 0,42 & 0,65 \\
$\begin{array}{c}\text { N-gain } \\
\text { terendah }\end{array}$ & 0,35 & 0,45 & 0,32 & 0,16 & 0,19 & 0,32 \\
$\begin{array}{c}\text { Rata-rata N- } \\
\text { gain }\end{array}$ & 0,42 & 0,57 & 0,45 & 0,30 & 0,30 & 0,31 \\
Kategori & Sedang & Sedang & Sedang & Sedang & Sedang & Sedang \\
\hline
\end{tabular}

Rata-rata $\mathrm{N}$-gain dari kelas eksperimen dan kelas kontrol memiliki kategori yang sedang. Kategori sedang berarti $\mathrm{N}$-gain memiliki nilai $\geq 0,3$ dan $<0,7$. Namun, rata-rata $\mathrm{N}$-gain kelas eksperimen lebih tinggi dari kelas kontrol, dimana $\mathrm{N}$-gain kelas kontrol sebesar 0,30 ini merupakan batas bawah pada kategori sedang yang mendekati kategori rendah. Tabel 7 menunjukkan rata-rata $\mathrm{N}$-gain ketiga tipe gaya belajar pada kelas eksperimen dalam kategori sedang. Tipe gaya belajar auditorial memiliki rata-rata $\mathrm{N}$-gain paling tinggi dan dua tipe gaya belajar lainnya yaitu visual dan kinestetik memiliki nilai rata-rata $\mathrm{N}$-gain yang tidak jauh berbeda. Rata-rata $\mathrm{N}$-gain tipe gaya belajar visual, auditorial, dan kinestetik di kelas eksperimen yang menggunakan model ADI lebih besar peningkatan ketampilan berpikir kritisnya dibandingkan dengan kelas kontrol yang menggunakan model non ADI.

Data N-gain yang diperoleh kemudian dilakukan uji normalitas yang dapat dilihat pada Tabel 8. 


\section{Pengaruh Penerapan Argument Driven Inquiry terhadap ... 19 I Kadek Irfando Dwikki Sadewa, Undang Rosidin, \& I Wayan Distrik}

Tabel 8. Uji Normalitas

\begin{tabular}{cccc}
\hline No & Parameter & Kelas Kontrol & Kelas Eksperimen \\
\hline 1 & Jumlah siswa & 31 & 31 \\
2 & Rata-rata nilai & 0,30 & 0,48 \\
3 & Asymp. Sig. (2-tailed) & 0,282 & 0,123 \\
\hline
\end{tabular}

Data nilai $\mathrm{N}$-gain keterampilan berpikir kritis siswa berdistribusi normal. Pada kelas kontrol Asymp. Sig. (2-tailed) 0,282 dan kelas eksperimen 0,123.

Nilai $\mathrm{N}$-gain yang telah dilakukan uji normalitas, kemudian dilakukan uji homogenitas. Data hasil uji homogenitas pada Tabel 9 sebagai berikut.

Tabel 9. Uji Homogenitas

\begin{tabular}{ccc}
\hline Jumlah Sampel & Levene Statistic & Sig. \\
\hline 62 & 2,388 & 0,128
\end{tabular}

Data dapat dikatakan memiliki varians yang homogen karena nilai signifikansi dari data tersebut lebih dari 0,05 .

Uji two way anova atau anava dua arah bertujuan untuk mengetahui apakah ada interaksi antar faktor yang di teliti. Uji ini juga untuk mengetahui apakah ada perbedaan rata-rata keterampilan berpikir kritis siswa kelas kontrol dengan kelas eksperimen berdasarkan tipe gaya belajar. Syarat dari uji ini yaitu dilakukan uji normalitas nilai residual standard terlebih dahulu untuk mengetahui nilai residual standard berdistribusi normal atau tidak, kemudian melakukan uji homogenitas dan uji two way anova.

Berikut Tabel 10 yang menampilkan hasil uji normalitas residual standar.

Tabel 10. Uji Normalitas Nilai Residual Standard

\begin{tabular}{|c|c|}
\hline Test of Standard Residual Normality & Sig. \\
\hline Kolmogorov-Smirnov ${ }^{a}$ & 0,200 \\
\hline Shapiro-Wilk & 0,328 \\
\hline
\end{tabular}

Nilai residual standard berdistribusi normal. Pada uji normalitas kolmogorov-smirnov dan shapiro-wilk nilai signifikansinya lebih dari 0,05. Setelah nilai residual standard dinyatakan berdistribusi normal, maka uji selanjutnya yaitu uji homogenitas varian variabel yang juga sebagai syarat untuk melakukan uji two way anova.

Berikut Tabel 11 yang menampilkan hasil uji homogenitas varian variabel.

Tabel 11. Uji Homogenitas Varian Variabel

\begin{tabular}{cccc}
\hline $\mathbf{F}$ & df1 & df2 & Sig. \\
\hline, 868 & 5 & 56 &, 508 \\
\hline
\end{tabular}

Berdasarkan output dari uji homogenitas varian variabel diperoleh nilai Sig. Sebesar 0,508. Karena nilai Sig lebih dari 0,05, maka dapat dikatakan bahwa varian variabel adalah homogen. Sehingga asumsi homogenitas dalam uji two way anova terpenuhi. Selanjutnya, membaca hasil uji two way anova pada varian variabel model pembelajaran dan tipe gaya belajar terhadap keterampilan berpikir kritis siswa.

Data hasil uji Two Way Anova dapat dilihat pada Tabel 12.

Tabel 12. Hasil Uji Two Way Anova

\begin{tabular}{ccccc}
\hline Source & Df & Mean Square & F & Sig. \\
\hline Corrected Model & 5 &, 124 & 19,073 &, 000 \\
Intercept & 1 & 9,223 & 1417,193 &, 000 \\
ModelPembelajaran & 1 &, 455 & 69,842 &, 000 \\
GayaBelajar & 2 &, 032 & 4,910 &, 011 \\
ModelPembelajaran * GayaBelajar & 2 &, 029 & 4,416 &, 017 \\
\hline
\end{tabular}


Dari hasil Tabel 12 dapat dilihat bahwa nilai Sig. model pembelajaran yaitu 0,000 dimana Sig. $<0,05$ maka dapat disimpulkan $\mathrm{H}_{0}$ ditolak dan $\mathrm{H}_{1}$ diterima. Jadi ada perbedaan keterampilan berpikir kritis antara penerapan model Argument Driven Inquiry (ADI) dan model non ADI. Hal ini diperkuat dengan nilai $\mathrm{N}$-gain keterampilan berpikir kritis pada penerapan model ADI lebih besar dari model non ADI sehingga membuktikan bahwa terdapat pengaruh model ADI terhadap keterampilan berpikir kritis siswa berdasarkan gaya belajar. Selanjutnya, nilai Sig. pada gaya belajar yaitu 0,011 dimana nilai Sig. $<0,05$ maka dapat disimpulkan bahwa ada perbedaan keterampilan berpikir kritis pada tipe gaya belajar, hal ini menunjukkan $\mathrm{H}_{0}$ ditolak dan $\mathrm{H}_{1}$ diterima. Nilai Sig. model pembelajaran terhadap gaya belajar yaitu 0,017 dimana nilai Sig. < 0,05 maka dapat dinyatakan bahwa ada interaksi model pembelajaran yang digunakan dengan tipe gaya belajar dalam peningkatan keterampilan berpikir kritis, hal ini menunjukkan $\mathrm{H}_{0}$ ditolak dan $\mathrm{H}_{1}$ diterima.

Hasil uji Two Way Anova pada gaya belajar menunjukkan $\mathrm{H}_{1}$ diterima, maka uji ini dilanjutkan ke tahap selanjutnya yaitu uji Post Hoc. Uji tersebut adalah uji lanjut atau uji untuk menilai adanya perbedaan signifikan antar kelompok yang menilai sampel manakah dari variabel tipe gaya belajar yang memiliki perbedaan signifikan.

Data uji Post Hoc gaya belajar pada kelas kontrol dan kelas eksperimen dapat dilihat pada Tabel 13

Tabel 13. Uji Post Hoc Kelas Kontrol dan Kelas Eksperimen

\begin{tabular}{ccc}
\hline \multirow{2}{*}{ Sampel 1 - Sampel 2 } & \multicolumn{2}{c}{ Sig. } \\
& Kelas Kontrol & Kelas Eksperimen \\
\hline Visual - Auditorial & 0,940 & 0,030 \\
Visual - Kinestetik & 0,938 & 0,506 \\
Auditorial - Kinestetik & 0,818 & 0,309 \\
\hline
\end{tabular}

Hasil uji post hoc kelas kontrol dengan keseluruhan sampel yang berhubungan memiliki nilai Sig. > 0,05 . Hal tersebut menunjukkan bahwa tidak ada perbedaan yang signifikan antar kelompok tipe gaya belajar. Nilai Sig. yang hampir sama dikeseluruhan sampel yang berhubungan ini semakin membuktikan tidak ada perbedaan keterampilan berpikir kritis berdasarkan tipe gaya belajar pada kelas kontrol yang menerapkan model pembelajaran non ADI.

Uji post hoc selanjutnya pada kelas eksperimen memperlihatkan nilai sig. visual dengan auditorial, yaitu 0,030 dimana nilai Sig. $<0,05$ maka ada perbedaan signifikan antara keterampilan berpikir kritis siswa visual dengan auditorial. Selanjutnya, tipe gaya belajar visual dengan kinestetik diperoleh nilai Sig. 0,506 dimana nilai Sig. > 0,05 maka tidak ada perbedaan signifikan antara keterampilan berpikir kritis siswa visual dengan kinestetik. Tipe gaya belajar selanjutnya yang dilakukan uji post hoc yaitu antara tipe auditorial dengan kinestetik, nilai Sig. yang diperoleh yaitu 0,309 dimana nilai Sig. $>0,05$ yang berarti tidak ada perbedaan yang signifikan antara keterampilan berpikir kritis siswa auditoria/ dengan kinestetik, tetapi jika dilihat dari nilai $\mathrm{N}$-gain yang diperoleh yaitu auditorial sebesar 0,57 dan kinestetik sebesar 0,45 dengan selisih nilai sebesar 0,12 maka masih terdapat perbedaan peningkatan keterampilan berpikir kritis namun tidak signifikan.

\section{Pembahasan}

Berdasarkan hasil uji two way anova dapat diketahui bahwa ada pengaruh yang signifikan dalam penerapan model Argument Driven Inquiry (ADI) terhadap keterampilan berpikir kritis berdasarkan tipe gaya belajar dan terdapat perbedaan rata-rata peningkatan keterampilan berpikir kritis pada tipe gaya belajar visual, auditorial, dan kinestetik dalam pembelajaran menggunakan model Argument Driven Inquiry (ADI) dibandingkan dengan pembelajaran menggunakan model kovensional (non ADI). Hasil penelitian ini juga sesuai dengan hasil penelitian yang dilakukan Fadila, Undang Rosidin, \& Hasnunidah (2018), dimana dalam hasil penelitiannya dinyatakan terdapat perbedaan keterampilan berpikir kritis siswa yang mendapatkan penerapan model Argument Driven Inquiry dibandingkan siswa yang mendapatkan penerapan model non ADI. Nilai rata-rata $\mathrm{N}$-gain keterampilan berpikir kritis kelas eksperimen lebih tinggi dibandingkan nilai rata-rata $\mathrm{N}$-gain kelas 
kontrol, hal ini dibuktikan melalui hasil perhitungan rata-rata $\mathrm{N}$-gain kelas eksperimen sebesar 0,48 dan rata-rata $\mathrm{N}$-gain kelas kontrol lebih rendah dari kelas eksperimen, yaitu 0,30.

Perbedaan nilai dan peningkatan keterampilan berpikir kritis siswa yang terjadi antara kelas eksperimen dan kelas kontrol dipengaruhi oleh beberapa faktor. Faktor yang paling terlihat adalah adanya penerapan model pembelajaran $A D I$ yang memiliki pembelajaran dengan berpusat pada siswa yang kolaboratif, memungkinkan siswa bebas mengeksplor kemampuan berpikirnya yang dituangkan dalam argumentasi ilmiah, bertukar pikiran melalui diskusi, sehingga mendapatkan hasil belajar yang lebih baik dan keterampilan berpikir kritis terasah. Hal tersebut serupa dengan teori yang disampaikan oleh Sampson dan Glein (2009) yang mengatakan bahwa Model pembelajaran Argument-Driven Inquiry (ADI) dirancang untuk mengembangkan kemampuan argumentasi ilmiah peserta didik. Model pembelajaran ini menekankan pada konstruksi dan validasi melalui kegiatan penyelidikan yang secara aktif dilakukan peserta didik. Dengan model ini, peserta didik diminta agar dapat menerapkan penyelidikan dari rancangan mereka sendiri, sehingga peserta didik dapat mengumpulkan dan menganalisis data, mengomunikasikan dan memberikan alasan mengenai ideide mereka terhadap siswa lainnya selama proses argumentasi-interaktif berlangsung.

Hasil pengujian two way anova pada tipe gaya belajar terhadap keterampilan berpikir kritis siswa diperoleh nilai Sig. sebesar 0,011 dimana nilai Sig. $<0,05$ yang artinya terdapat perbedaan rata-rata peningkatan keterampilan berpikir kritis siswa pada masing-masing tipe gaya belajar yang diterapkan model ADI. Peningkatan keterampilan berpikir kritis siswa auditorial lebih tinggi dibandingkan siswa visual dan kinestetik, hal ini disebabkan siswa auditorial tampak lebih aktif dalam komunikasi secara verbal yang mendukung kemampuan argumentasi yang baik, dimana pada model Argument Driven Inquiry (ADI) ini siswa dituntut untuk banyak memberikan argumentasi atau berkomunikasi antar sesama siswa untuk menyampaikan argumentasinya. Hal ini sesuai dengan hasil penelitian yang dikemukakan oleh Sutrisno (2013), hasil penelitian menyatakan bahwa prestasi siswa bergaya belajar auditorial lebih baik daripada visual dan kinestetik serta prestasi siswa bergaya belajar visual lebih baik daripada kinestetik. Hal ini bisa terjadi, karena sebagian besar proses pembelajaran tidak terlepas oleh komunikasi verbal sehingga mempermudah siswa bergaya belajar auditorial dalam memahami materi.

Siswa kinestetik memiliki keterampilan berpikir kritis lebih tinggi dibandingkan siswa visual namun lebih rendah dari siswa auditorial. Hal ini disebabkan siswa kinestetik juga aktif dalam pembelajaran yang menyukai belajar dengan aktifitas fisik, dimana pada model ADI ini siswa juga dituntut untuk banyak melakukan aktifitas fisik seperti melakukan percobaan ilmiah dan mengunjungi kelompok lain untuk saling bertukar argumen namun siswa kinestetik memiliki kelemahan seperti menyukai kegiatan coba-coba yang terkadang tanpa mendengarkan instruksi terlebih dahulu. Keterampilan berpikir kritis siswa visual paling rendah diantara siswa auditorial dan kinestetik. Hal ini disebabkan karakteristik siswa visua/ berbanding terbalik dengan siswa auditoria/ dimana siswa visual kurang dalam komunikasi secara lisan maupun menerima instruksi secara lisan. Sehingga, siswa visual kurang aktif dalam penerapan model ADI.

Interaksi antara model pembelajaran Argument Driven Inquiry dengan tipe gaya belajar memiliki pengaruh dalam peningkatan keterampilan berpikir kritis siswa. Hal ini dibuktikan melalui nilai Sig. yang diperoleh pada uji two way anova yaitu 0,017 dimana nilai Sig. $<0,05$. Interaksi ini terlihat ketika penerapan model ADI yang dalam kegiatannya terdapat penyelidikan pada LKPD, kegiatan praktikum, diskusi dan penyampaian argumentasi dapat menumbuhkan keterampilan berpikir kritis siswa dengan tipe gaya belajar yang berbeda-beda. Model pembelajaran ADI dapat mencakup karakteristik yg dimiliki siswa bergaya belajar visual, auditorial, serta kinestetik dalam peningkatan keterampilan berpikir kritis siswa.

Interaksi pada siswa bergaya belajar visual dengan penerapan model ADI terlihat ketika kegiatan penyelidikan dengan LKPD, siswa visual memiliki kelebihan membaca dengan teliti tiap kegiatan penyelidikan yang ada di LKPD. Siswa auditorial memiliki kelebihan dalam kegiatan sesi argumentasi dengan penyampaian verbal yang baik sehinggga terjadi interaksi antara kelebihan yang 
dimiliki siswa tipe gaya belajar auditorial dengan kegiatan argumentasi yang terdapat dalam penerapan model pembelajaran ADI, sedangkan siswa kinestetik memiliki kelebihan dalam kegiatan praktikum berbasis laboratorium, dimana ketika kegiatan praktikum siswa melakukan percobaan dengan melibatkan kegiatan fisik. Hal ini memiliki interaksi dengan kelebihan yang dimiliki siswa bergaya belajar kinestetik yaitu menyukai kegiatan coba-coba dan kegiatan yang melibatkan fisik. Temuan interaksi dalam penelitian ini memberi petunjuk bahwa pengaruh penerapan model pembelajaran ADI bergantung pada masing-masing tipe gaya belajar dalam meningkatkan keterampilan berpikir kritis siswa.

\section{PENUTUP}

Berdasarkan hasil dan pembahasan, maka dapat ditarik kesimpulan bahwa terdapat pengaruh yang signifikan penerapan model pembelajaran Argument Driven Inquiry (ADI) terhadap keterampilan berpikir kritis siswa pada tipe gaya belajar visual, auditorial, dan kinestetik, ditunjukkan dengan nilai Sig., yaitu 0,000. Kemudian, terdapat perbedaan keterampilan berpikir kritis siswa antara ketiga tipe gaya belajar, yaitu visual, auditorial, dan kinestetik menggunakan model Argument Driven Inquiry (ADI). Nilai rata-rata keterampilan berpikir kritis siswa auditorial lebih tinggi dari siswa visual dan kinestetik. Hal ini disebabkan siswa auditorial tampak lebih aktif dalam komunikasi secara lisan yang mendukung kemampuan argumentasi yang baik. Selanjutnya, terdapat interaksi antara penerapan model pembelajaran Argument Driven Inquiry (ADI) dengan tipe gaya belajar visual, auditorial, dan kinestetik dalam peningkatan keterampilan berpikir kritis.

Saran bagi guru, pembelajaran dengan menerapkan model pembelajaran Argument Driven Inquiry (ADI) dapat dijadikan salah satu alternatif bagi guru di sekolah dalam upaya meningkatkan keterampilan berpikir kritis siswa. Kedua, guru perlu memahami tiap tipe gaya belajar supaya dapat memberikan pendekatan lebih terhadap tipe gaya belajar yang lemah dalam penerapan model Argument Driven Inquiry (ADI) untuk dapat aktif mengikuti proses pembelajaran.

\section{DAFTAR PUSTAKA}

Aspirani, E. (2017). Pengaruh Model Pembelajaran Kooperatif dan Kemampuan Awal terhadap Hasil Belajar Peserta Didik (Studi pada Materi Pokok Hidrolisis Garam di Kelas XI IPA SMA Negeri 1 Mare). Chemica: Jurnal IImiah Kimia dan Pendidikan Kimia, 18(2), 56-65.

Ennis, RH. (2011). The Nature Of Critical Thinking: An Outline of Critical Thinking Dispositions and Abilities. [Online]. Tersedia: http://faculty.ed.uiuc.edu/rhennis/documents/TheNatureofCriticalThinking 51711 000.pdf.

Fadila, N. (2018). Pengaruh Penerapan Model Argument Driven Inquiry terhadap Keterampilan Berpikir Kritis Siswa SMP berdasarkan Perbedaan Tipe Kepribadian. Journal of Komodo Science Education, 1(1), 39-52

Permendikbud. (2016). Kurikulum 2013 Mata Pelajaran IPA SMP/MTS. Jakarta

Phelps, W. (2012). Argument-Driven Inquiry as a way to help students learn how to participate in scientific argumentation and craft written arguments, an exploratory study. Science Education, 95(2), 217-257.

Sampson, V., \& Gleim, L. (2009). Argument-driven inquiry to promote the understanding of important concepts \& practices in biology. The American biology teacher, 71(8), 465-472.

Harie, S. (2016). Pengaruh Metode Pembelajaran dan Gaya Belajar terhadap Kemampuan Berpikir Kritik Biologi. Formatif: Jurnal IImiah Pendidikan MIPA, 5(3): 257-267. 
Sugiyono. (2012). Metode Penelitian Kunatitatif Kualitatif dan R\&D. Bandung: Alfabeta.

Sularso, A. (2015). Pengaruh Penggunaan Model Pembelajaran Inkuiri Terbimbing Terhadap Kemampuan Berpikir Kritis Siswa Ditinjau dari Gaya Belajar Siswa. Bio-Pedagogi, 4(2), 1-4.

Sutrisno. 2013. Eksperimentasi Model Pembelajaran Kooperatif Tipe STAD dan TPS dengan Pendekatan Savi Terhadap Prestasi dan Motivasi Belajar Ditinjau dari Gaya Belajar Siswa. Jurnal Pembelajaran Matematika, 1(7). 